ORIGINAL ARTICLE / ARTIGO ORIGINAL

\title{
Sexual behavior of school-aged adolescents in the city of Goiânia, Goiás
}

\author{
Comportamento sexual de adolescentes escolares da cidade de Goiânia, Goiás \\ Reinaldo Satoru Azevedo Sasaki', Márcia Maria de Souza", Cláudio Rodrigues Leles"I", \\ Deborah Carvalho Maltalv, Luciana Monteiro Vasconcelos Sardinhalv, \\ Maria do Carmo Matias Freire"II
}

\begin{abstract}
Objective: To investigate the characteristics of sexual behavior in school-aged adolescents and possible differences regarding sex and type of school. Methods: Cross-sectional study using data from the National Adolescent School-based Health Survey (PeNSE) 2009, carried out by the Brazilian Ministry of Health, in partnership with the Brazilian Institute of Geography and Statistics (IBGE). The sample consisted of 3,099 $9^{\text {th }}$ graders living in Goiânia, State of Goiás, Brazil, mostly aged between 13 to 15 years old, who answered a self-applicable questionnaire on risk and protective health factors. The Rao-Scott test was used in the statistical analysis, considering the complex sample design. Results: The prevalence of sexual intercourse was of $26.5 \%$ $(95 \%$ CI $23.8-29.4)$ at least once in life and of $18.5 \%(95 \%$ CI $16.5-20.8)$ in the last year. Both behaviors were more frequent among male students and among those attending public schools. Most of the respondents had their first intercourse at the age of 13 or younger, with up to 3 partners. They had also used a pregnancy prevention method in the last intercourse, and received guidance on prevention at school. The age of the first intercourse was earlier and the number of partners was higher among male students. More females and those attending public schools reported having received information on pregnancy prevention. Guidance on STD/AIDS was also more frequent in public schools. Conclusion: Results showed a need for health education measures involving education and health professionals, as well as parents, to reduce the discrepancies found regarding sex and type of school.
\end{abstract}

Keywords: Sex. Sexual and reproductive health. Adolescent. School health. Sexual behavior. Sexual partners.

'Department of Gynecology and Obstetrics, Universidade Federal de Goiás - Goiânia (GO), Brazil.

"Nursing School at Universidade Federal de Goiás - Goiânia (GO), Brazil.

"'Dental School at Universidade Federal de Goiás - Goiânia (GO), Brazil.

"vealth Surveillance Secretariat, Ministry of Health - Brasília (DF), Brazil.

Corresponding author: Reinaldo Satoru Azevedo Sasaki. Departamento de Ginecologia e Obstetrícia da Universidade Federal de Goiás. Alameda Cel. Joaquim Bastos, 134, Setor Marista, CEP: 74175-150, Goiânia, G0, Brasil. E-mail: reinaldo_sasaki@yahoo.com.br Conflict of interests: nothing to declare - Financing source: none. 
RESUMO: Objetivo: Investigar as características do comportamento sexual de adolescentes escolares e verificar se há diferenças em relação ao sexo dos estudantes e ao tipo de escola. Métodos: Estudo transversal utilizando dados da Pesquisa Nacional de Saúde do Escolar (PeNSE) 2009, realizada pelo Ministério da Saúde em parceria com o IBGE. A amostra foi composta por 3.099 escolares do $9^{\circ}$ ano residentes em Goiânia (GO), com predomínio das idades de 13 a 15 anos, que responderam um questionário sobre fatores de risco e proteção à saúde. Na análise estatística, foi utilizado o teste de Rao-Scott, considerando o efeito do desenho amostral para amostras complexas. Resultados: A prevalência de relação sexual alguma vez na vida foi de $26,5 \%$ (IC95\% 23,8 - 29,4), e, no último ano, foi de 18,5\% (IC95\% 16,5 - 20,8), sendo mais frequentes entre os meninos e estudantes de escolas públicas. A maioria teve a primeira relação com 13 anos ou menos, com até 3 parceiros, utilizou algum método contraceptivo na última relação e recebeu orientação sobre prevenção na escola. A idade da primeira relação foi mais precoce e o número de parceiros foi mais elevado entre os meninos. O relato de orientações recebidas sobre prevenção de gravidez foi mais frequente entre meninas e nas instituições privadas. Nestas, foi também mais elevado o relato de orientações sobre DST/AIDS. Conclusão: Os resultados mostraram a necessidade de ações educativas, buscando reduzir as discrepâncias encontradas em relação ao sexo e o tipo de escola, com envolvimento de profissionais das áreas da educação e saúde e dos pais.

Palavras-chave: Sexo. Saúde sexual e reprodutiva. Adolescente. Saúde escolar. Comportamento sexual. Parceiros sexuais.

\section{INTRODUCTION}

Adolescence constitutes a transition period between childhood and adulthood, with major transformations in social, cognitive emotional and body aspects. In this period, the opportunities to work on health are great and future patterns of health behavior in adulthood are established ${ }^{1}$.

Among the changes, those regarding the aspects of affective relationships stand out, especially the phenomenon of sexuality ${ }^{2,3}$. The beginning of sexual activities is an important mark in the lives of people, and it stands out in adolescence due to the characteristics of that phase, since young people search for affirming their own identity and are looking forward to new experiences ${ }^{4}$. Generally, because adolescents feel young, healthy and curious to new situations, they can adopt sexual behaviors without protection, thus making them vulnerable to conditions and infections, especially Sexually Transmitted Diseases (STDs) and early pregnancy,

The sexual behavior of adolescents should be studied by considering social inequities, sexual culture, sex and schooling, which are important determining factors for risk behaviors and can result in morbidities in this population. Therefore, it is important 
to know the reality of this population group in the different scenarios in which they are inserted. Most Brazilian young people attend educational institutions, and this environment is not only recognized as a social learning space, but also as a place of socialization and discussions concerning sexual education ${ }^{7}$.

The sexual behavior of boys was little studied up until recently, and analyses were mostly focused on girls ${ }^{8,9}$. Studies on this subject are also mostly conducted in public schools, since researchers can access these institutions more easily, therefore, there are few studies comparing both types of schools (public and private ones) ) $^{10-13}$. The results showed different risk behaviors and levels of information concerning sex and type of school ${ }^{10-13}$.

The National Adolescent School-based Health Survey (PeNSE), conducted in 2009 by the Ministry of Health, together with the Brazilian Institute of Geography and Statistics, was pioneer in the national scenario, with the objective of knowing the risk and protective factors among Brazilian adolescents ${ }^{14}$. The study showed that $30.5 \%$ of the Brazilian adolescents living in the capitals have already had sexual intercourse, mostly boys (43.7\%) in comparison to girls (18.7\%), and among students attending public schools (33.1\%). Out of those who have had intercourse, $40.1 \%$ reported having a single partner in life ${ }^{4}$.

Previous studies with data from PeNSE 2009 presented important results about the national sample, and also some data describing each analyzed capital ${ }^{4,15,16}$. However, it is also relevant to do further analyses on the situations of capitals separately, in order to establish comparisons with the national scenario. Based on local reality, more adequate strategies can be implemented in order to benefit the involved parties. Studies on the sexual behavior of adolescents in the city of Goiânia are scarce and refer to the knowledge about modes of STD transmission and the use of contraceptive methods ${ }^{17-19}$. Therefore, the objective of this study was to describe the characteristics regarding the sexual behavior of students in the city of Goiannia (GO) and to verify if there are any differences concerning the sex of students and the type of school.

\section{METHODS}

A cross-sectional study using the data base of a probability sample of $9^{\text {th }}$ graders in elementary school of public and private schools in the city of Goiânia, Goiás, Brazil, who participated in PeNSE $2009^{14}$. The study used a two-stage cluster sampling, in which the primary sampling units were schools and the secondary units were $9^{\text {th }}$ grade classrooms of the selected schools. The sample of students was formed by all of the students in the selected classrooms who were present at the time of data collection and who accepted to participate. Exclusion criteria were students attending the night time period, non-habitual students, and those who refused answering the questionnaire. Data collection was conducted by State 
teams of IBGE from March to June, 2009. In Goiânia, 73 schools and 112 classrooms were sampled, with a total of 3,727 enrolled students.

This study included adolescents who answered the questions about sex (female/male) and about sexual behavior, accounting for 3,099 participants aged between 11 and 17 years old, but most were aged between 13 and 15 years old. The following variables concerning sexual behavior were analyzed: occurrence of sexual intercourse, characteristics of sexual behavior and recommendations on prevention received at school. These variables were analyzed according to the sex of the student and the administration of the school (public or private).

The sexual behavior of the adolescent was obtained from the question "Have you ever had sexual intercourse?", with the response categories "Yes" and "No". The sexual intercourse variables in the past 12 months were also investigated, such as age of the first sexual intercourse, number of sexual partners, use of contraceptive methods in the last intercourse, recommendations at school about preventing pregnancy, AIDS or other STDs, or about how to obtain condoms.

At first, the frequencies of the variables were calculated (percentage and respective $95 \%$ confidence intervals). For the analysis of associations between each of the variables related to sexual behavior and to the variables sex and type of school, the Rao-Scoot corrections to the $\chi^{2}$ test were used. Since this is a cluster sample, all of the analyses considered the sampling design effect for complex samples, by using sample weights calculated with the Complex Sample module of the statistical software SPSS, version 17.0. The sampling weight represents the probability of each student to participate in the sample, according to the school he or she attends ${ }^{20}$.

The PeNSE project was approved by the National Research Ethics Commission - CONEP, report n. 005, June $10^{\text {th }}, 2009$, registered with n. 11,537.

\section{RESULTS}

Out of the 3,099 respondents, approximately half of them were female participants $(51.6 \%)$. As to skin color/self-reported ethnicity, less than half of them were mulattos (41.1\%), 39.0\% were white, $10 \%$ were black, 5.3\% were Asian and 3.9\% were indigenous. Almost half of the participants were 14 years old (49.8\%), while $29.7 \%$ were 13 years old or younger, and $20.4 \%$ were 15 years old or older. More than half of the students (66.1\%) attended public schools.

The prevalence of ever having sexual intercourse was of $26.5 \%$ and, in the past 12 months, of $18.5 \%$ (Table 1 ). More than half of the adolescents who have already had sexual intercourse initiated their sexual activities at the age of 13 or younger (63.2\%). The number of partners ranged from 1 to 6 , and a single partner was the most frequent category (41.9\%). Most adolescents claimed to have used some method to avoid pregnancy in the last intercourse $(71.9 \%)$ and to have used a condom in the 
last intercourse (75.9\%). Most of them also claimed to have been advised about sexual health at school concerning the prevention of pregnancy $(82.1 \%)$, AIDS and other STDs $(89.6 \%)$, and about how to obtain condoms $(70.1 \%)$.

The prevalence of ever having sexual intercourse and in the past twelve months was higher among male students in comparison to female ones, and among those attending public schools in relation to the ones who studied in private schools $(\mathrm{p}<0.001)$. Among male students, the age at the first intercourse was younger and the number of partners was higher in comparison to females $(\mathrm{p}<0.001)$, and there was no statistical difference between the type of school and sex when compared to the use of any preventive method in the past relationship (Tables 2 and 3 ).

The report of recommendations received at school about preventing pregnancy was more common among female adolescents and in public schools $(\mathrm{p}<0.05)$. Information about preventing pregnancy and about AIDS and other STDs was more frequente in private schools $(\mathrm{p}<0.05)$. There were no differences between groups as to the recommendation about how to obtain a condom (Table 4).

Table 1. Frequency distribution of the variables analyzed in the study. Adolescents in the city of Goiania. National Adolescent School-based Health Survey (PeNSE), Brazil, 2009.

\begin{tabular}{|c|c|c|c|}
\hline Variables & Category & $\mathrm{n}$ & $\%(95 \% \mathrm{Cl})^{*}$ \\
\hline \multicolumn{4}{|l|}{ Sexual behavior } \\
\hline \multirow{2}{*}{ Ever had sexual intercourse $(n=3099)$} & Yes & 823 & $26.5(23.8-29.4)$ \\
\hline & No & 2276 & $73.5(70.6-76.2)$ \\
\hline \multirow{2}{*}{$\begin{array}{l}\text { Sexual intercourse in the past } \\
12 \text { months }(n=3048)\end{array}$} & Yes & 563 & $18.5(16.5-20.8)$ \\
\hline & No & 2485 & $81.5(79.2-83.5)$ \\
\hline \multirow{3}{*}{ Age of the first sexual intercourse $(n=808)$} & $<13$ years old & 500 & $63.2(58.8-67.4)$ \\
\hline & 14 years old & 188 & $22.0(18.8-25.7)$ \\
\hline & $>15$ years old & 120 & $14.8(12.0-18.1)$ \\
\hline \multirow{4}{*}{ Number of partners $(n=811)$} & 1 & 346 & $41.9(38.2-45.6)$ \\
\hline & 2 to 3 & 220 & $27.4(24.3-30.7)$ \\
\hline & 4 to 6 & 168 & $21.0(18.0-24.2)$ \\
\hline & Doest not remember & 77 & $9.8(8.2-11.7)$ \\
\hline \multirow{3}{*}{$\begin{array}{l}\text { Use of contraceptive methods } \\
\text { in the last intercourse }(n=819)\end{array}$} & Yes & 594 & $71.9(67.9-75.6)$ \\
\hline & No & 176 & $22.4(18.8-26.2)$ \\
\hline & Does not know & 49 & $5.8(4.2-8.0)$ \\
\hline
\end{tabular}


Table 1. Continuation.

\begin{tabular}{|c|c|c|c|}
\hline Variables & Category & $\mathrm{n}$ & $\%(95 \% \mathrm{Cl})^{*}$ \\
\hline \multirow{3}{*}{$\begin{array}{l}\text { Use of condom in the last } \\
\text { intercourse }(n=817)\end{array}$} & Yes & 625 & $75.9(73.2-78.5)$ \\
\hline & No & 171 & $21.7(19.0-24.7)$ \\
\hline & Does not know & 21 & $2.3(1.5-3.7)$ \\
\hline \multicolumn{4}{|l|}{ Orientations about sexual health at school } \\
\hline \multirow{3}{*}{ Preventing pregnancy $(n=3041)$} & Yes & 2475 & $82.1(79.2-84.6)$ \\
\hline & No & 387 & $12.4(10.5-14.5)$ \\
\hline & Does not know & 179 & $5.6(4.5-6.8)$ \\
\hline \multirow{3}{*}{$\begin{array}{l}\text { Prevention of AIDS and } \\
\text { other STDs }(n=3055)\end{array}$} & Yes & 2733 & $89.6(88.0-91.0)$ \\
\hline & No & 233 & $7.5(6.4-8.8)$ \\
\hline & Does not know & 89 & $2.9(2.2-3.6)$ \\
\hline \multirow{3}{*}{ How to obtain a condom $(n=3055)$} & Yes & 2132 & $70.1(67.0-73.1)$ \\
\hline & No & 661 & $21.5(19.1-24.0)$ \\
\hline & Does not know & 262 & $8.4(7.2-9.7)$ \\
\hline
\end{tabular}

*Corrected for sample design.

Table 2. Sexual behavior of school-aged adolescents in the city of Goiania according to sex. National Adolescent School-based Health Survey (PeNSE), Brazil, 2009.

\begin{tabular}{|c|c|c|c|}
\hline Variables & $\begin{array}{l}\text { Male } \\
\mathrm{n}(\%)^{*}\end{array}$ & $\begin{array}{l}\text { Female } \\
\mathrm{n}(\%)^{*}\end{array}$ & p-value ${ }^{* *}$ \\
\hline Ever had sexual intercourse $(n=823)$ & $584(38.3)$ & $239(15.2)$ & $<0.001$ \\
\hline Intercourse in the past 12 months $(n=563)$ & $379(25.4)$ & $184(12.0)$ & $<0.001$ \\
\hline \multicolumn{4}{|l|}{ Age of first sexual intercourse $(n=808)$} \\
\hline$<13$ years old & $383(68.8)$ & $117(49.8)$ & $<0.001$ \\
\hline 14 years old & $120(19.2)$ & $68(28.6)$ & \\
\hline$>15$ years old & $70(11.9)$ & $50(21.6)$ & \\
\hline \multicolumn{4}{|l|}{ Number of partners $(n=734)$} \\
\hline 1 & $208(35.0)$ & $138(58.5)$ & $<0.001$ \\
\hline 2 to 3 & $170(29.6)$ & $50(21.9)$ & \\
\hline 4 to 6 & $138(24.2)$ & $30(13.2)$ & \\
\hline $\begin{array}{l}\text { Use of contraceptive method } \\
\text { in the last intercourse }(n=594)\end{array}$ & $410(70.6)$ & $184(75.0)$ & 0.048 \\
\hline Use of condom in the last intercourse $(n=625)$ & $447(77.0)$ & $178(73.3)$ & 0.292 \\
\hline
\end{tabular}

${ }^{*}$ Corrected for sample design; ${ }^{* *}$ Rao-Scott test. 
Table 3. Sexual behavior of school-aged adolescents in the city of Goiania according to type of school. National Adolescent School-based Health Survey (PeNSE), Brazil, 2009.

\begin{tabular}{|c|c|c|c|}
\hline Variables & $\begin{array}{l}\text { Public school } \\
\mathrm{n}(\%)^{*}\end{array}$ & $\begin{array}{c}\text { Private school } \\
n(\%)^{*}\end{array}$ & $p$-value ${ }^{* *}$ \\
\hline Ever had sexual intercourse $(n=823)$ & $627(30.4)$ & $196(18.8)$ & $<0.001$ \\
\hline Intercourse in the past 12 months $(n=563)$ & $418(20.9)$ & $145(14.0)$ & $<0.001$ \\
\hline \multicolumn{4}{|l|}{ Age of first sexual intercourse $(n=808)$} \\
\hline$<13$ years old & $389(64.1)$ & $111(60.4)$ & 0.512 \\
\hline 14 years old & $135(20.8)$ & $53(25.8)$ & \\
\hline$>15$ years old & $92(15.1)$ & $28(13.7)$ & \\
\hline \multicolumn{4}{|l|}{ Number of partners $(n=734)$} \\
\hline 1 & $255(41.8)$ & $91(44.2)$ & 0.535 \\
\hline 2 to 3 & $172(28.1)$ & $48(25.2)$ & \\
\hline 4 to 6 & $125(20.1)$ & $43(23.7)$ & \\
\hline $\begin{array}{l}\text { Use of contraceptive method } \\
\text { in the last intercourse }(n=594)\end{array}$ & $451(71.7)$ & $143(72.5)$ & 0.501 \\
\hline Use of condom in the last intercourse $(n=625)$ & $477(76.6)$ & $148(73.9)$ & 0.376 \\
\hline
\end{tabular}

${ }^{*}$ Corrected for sample design; **Rao-Scott test.

Table 4. Counseling on sexual health at school among school-aged adolescents in the city of Goiânia according to sex and type of school. National Adolescent School-based Health Survey (PeNSE), Brazil, 2009.

\begin{tabular}{|l|c|c|c|c|c|c}
\hline Variables & $\begin{array}{c}\text { Male } \\
\mathrm{n}(\%)^{*}\end{array}$ & $\begin{array}{c}\text { Female } \\
\mathrm{n}(\%)^{*}\end{array}$ & p-value* & $\begin{array}{c}\text { Public } \\
\text { school } \\
\mathrm{n}(\%)^{*}\end{array}$ & $\begin{array}{c}\text { Private } \\
\text { school } \\
\mathrm{n}(\%)^{*}\end{array}$ & $\mathrm{p}^{\text {-value** }}$ \\
\hline $\begin{array}{l}\text { Counseling on pregnancy } \\
\text { prevention } \\
(\mathrm{n}=2475)\end{array}$ & $\begin{array}{c}1158 \\
(80.1)\end{array}$ & $\begin{array}{c}1317 \\
(83.9)\end{array}$ & 0.037 & $1650(85.3)$ & $825(89.9)$ & 0.020 \\
\hline $\begin{array}{l}\text { Counseling about AIDS and } \\
\text { other STDs (n=2733) }\end{array}$ & $\begin{array}{c}1297 \\
(88.1)\end{array}$ & $\begin{array}{c}1436 \\
(91.0)\end{array}$ & 0.097 & $1840(91.4)$ & $893(93.9)$ & 0.024 \\
\hline $\begin{array}{l}\text { Orientation about how to } \\
\text { obtain a condom (n=2132) }\end{array}$ & $\begin{array}{c}1036 \\
(70.4)\end{array}$ & $\begin{array}{c}1096 \\
(69.9)\end{array}$ & 0.345 & $1439(75.8)$ & $693(78.0)$ & 0.437 \\
\hline
\end{tabular}

${ }^{*}$ Corrected for sample design; **Rao-Scott test.

\section{DISCUSSION}

This study was the first one to assess the prevalence of sexual intercourses and its association with the sex of the students and the type of school in the city of Goiânia. Among 
its relevant aspects, the use of a national data base with a well-established methodology and representative sample of the Brazilian capitals stands out ${ }^{14}$.

The characteristics of the sample are also important, since they contemplate both the female and the male sex in their real proportions, since even in the Cairo Conference ${ }^{21}$ boys did not get the necessary attention from the point of view of the research, evaluation and actions.

The prevalence of ever having sexual intercourse among students in Goiânia (26.5\%) was lower to that observed in the national sample of PeNSE $(30.5 \%)^{4}$. Studies conducted with adolescents in schools or in households of other cities in Brazil showed higher prevalence, but the samples included older individuals ${ }^{10-12,22-24}$.

As to the distribution by sex, it was higher among boys, which is in accordance with national data from PeNSE $2009^{4}$ and with studies conducted in other locations ${ }^{10-13,22-24}$. In the United States, the Youth Risk Behavior Surveillance System assessed students that would correspond from $9^{\text {th }}$ graders of elementary school to those attending the $3^{\text {rd }}$ year of high school in Brazil, in 2009, and did not find differences between boys and girls as to the report of sexual intercourse ${ }^{25}$. The different results may have been caused by cultural factors and age, since the sample of the American study included older individuals.

The results concerning the type of school showed that the prevalence of ever having sexual intercourse was higher in public institutions in comparison to private institutions. A previous study conducted with students aged 15 to 18 years old in the metropolitan region of São Paulo confirms this finding ${ }^{11}$. Likewise, the national sample of PeNSE demonstrated that students attending public schools had more sexual intercourses $(30.4 \%)$ than those in private schools $(18.8 \%)^{4}$. Malta et al. ${ }^{4}$ considered that the higher prevalence in public schools can be explained by differences in the age group, since in such institutions $9^{\text {th }}$ graders are older than the ones in private schools, and older students present higher prevalence of sexual initiation.

The percentage of adolescents who had from four to six partners (21\%) was the same one found in the national data of $\mathrm{PeNSE}^{4}$. The high number of partners is a reason of concern in the health field, since it can increase the chances of transmitting HIV and other STD. Therefore, educational actions are necessary to reduce the vulnerability of teenagers, thus respecting their choices. The creation of the School Health Program (PSE) by the Federal Government in $2007^{26}$ is an example of an initiative that includes the sexual and reproductive health approach in the context of schools in the country, which may have a positive impact on this matter.

Age is an important factor to be considered, because in case the probability of initiating in sexual life at this stage is known, educational and preventive actions can be employed before the first sexual intercourse. Vieira et al. ${ }^{17}$ analyzed sexually active female students aged between 15 and 19 years old, living in a sanitary district of Goiânia, and found that more than half of them had their first sexual intercourse at the age of 15 or younger. According to a study conducted by the Ministry of Health, the frequency of 
women who initiated their sexual activities before the age of 14 was superior to $13.6 \%$ and $32.3 \%$ in 1984 and 1998 , so it more than doubled ${ }^{27}$. In our study, we observed that most adolescents had their first sexual intercourse at the age of 13 or younger $(63.2 \%)$, and this percentage is higher than the one found nationally $(47.1 \%)^{4}$. Sexual initiation at younger ages has been reported in other studies ${ }^{10,12,24,28}$. Most of the time, boys begin their sexual activities earlier than girls ${ }^{10,12,24,29}$.

In this study, the high prevalence of reports concerning the use of male condoms and being advised about matters related to sexual health deserves attention. This result is in accordance with that observed in the national sample of PeNSE ${ }^{4}$. However, in another investigation conducted by the Ministry of Health in 2009, the Survey of knowledge, attitudes and practices in the Brazilian population, only $33.6 \%$ of female participants and $57.4 \%$ of male participants aged between 15 and 24 years old used condoms in all intercourses ${ }^{30}$. In a previous study conducted in the city of Goiânia, the inconsistent use of condoms (sometimes, rarely and never) accounted for $79.5 \%$ of the cases among female adolescents ${ }^{17}$. Besides, in a city of the Southeast region ${ }^{31}$, there was a gap between the knowledge and the use of contraceptive methods, since adolescents knew about them, but did not use them.

With regard to recommendations about preventing pregnancy and STD/AIDS, the fact that these were less frequent in public institutions stands out, since it is a known fact that such institutions usually receive students coming from poorer socioeconomic strata, who are, therefore, more prone to health risk factors. Similar results were observed in the national sample of PeNSE concerning STD/AIDS, while the recommendation about obtaining a condom was more common in public schools ${ }^{15}$. In these institutions, there are usually public health programs, especially those addressed to preventing STDs, which can contribute with higher levels of information among students, therefore resulting in safer practices, even though they do not necessarily reduce the frequency of sexual intercourses. However, these measures seem to have not been sufficient to overcome the existing inequalities.

Some considerations should be made concerning the sample, since it is limited to students who frequently attend school, therefore excluding the adolescents who are not part of the regular educational system and those who live in the streets. However, this situation is usually observed in individuals aged 15 to 17 years old, who had lower representativeness in the sample of PeNSE. Besides, the coverage of the educational system, when considering younger adolescents (from 10 to 14 years old) was high in $2007^{32}$, which served as a base for the sampling calculation of this research. This sample does not contemplate students in night time periods. These can be different from those in the day time periods, since these students usually live in poorer economic situations, have different objectives and are inserted in the work market. Among them, school evasion rates are higher, and usually the quality of education is worse ${ }^{33}$. 


\section{CONCLUSION}

It is possible to conclude that the sexual behavior of students in Goiânia, in 2009, was associated with sex and type of schools they attended, and the prevalence was the more frequent intercourses among boys from public schools. These results can contribute with the planning and the evaluation of actions in the sexual health field addressed to this population group. By analyzing the sexual behavior and its associated factors, parents, educators and health professionals can be provided with information to identify which students have more chances of initiating or having initiated sexual life in order to promote sexual health actions, so that, in this stage of life changes, the risks of such a behavior can be minimized. When being early instituted, sexual orientation has the potential of minimizing the intercurrences that might compromise the sexual and reproductive health of the adolescent. Male adolescents deserve special attention, since their sexual initiation is more frequent, earlier and includes more partners. Public schools should expand and strengthen their health education actions, focusing on sexual behavior. Generally, sexual orientation in schools has the potential of contributing with the well-being of adolescents while experiencing their current and future sexuality.

\section{REFERENCES}

1. Sawyer SM, Afifi RA, Bearinger LH, Blakemore SJ, Dick B, Ezeh AC et al. Adolescence: a foundation for future health. Lancet 2012; 379(9826): 1630-40.

2. Abramovay M, Castro MG, Silva LB. Juventudes e sexualidade. Brasília: UNESCO Brasil; 2004.

3. Moraes SP, Vitalle MSS. Direitos sexuais e reprodutivos na adolescência. Rev Assoc Med Bras 2012; 58(1): 48-52.

4. Malta DC, Silva MAI, Mello FCM, Monteiro RA, Porto DL, Sardinha LMV et al. Saúde sexual dos adolescentes segundo a Pesquisa Nacional de Saúde dos Escolares. Rev Bras Epidemiol 2011; 14(1): 147-56.

5. Alves CA, Brandão ER. Vulnerabilidades no uso de métodos contraceptivos entre adolescentes e jovens: interseções entre políticas públicas e atenção à saúde. Ciênc Saúde Coletiva 2009; 14(2): 661-70.

6. Dias FLA, Silva KL, Vieira NFC, Pinheiro PNC, Maia CC. Riscos e vulnerabilidades relacionados à sexualidade na adolescência. Rev Enferm UERJ 2010; 18(3): 456-61.

7. Moizes JS, Bueno SMV. Compreensão sobre sexualidade e sexo nas escolas segundo professores do ensino fundamental. Rev Esc Enferm 2010; 44(1): 205-12.

8. Figueroa-Perea JG. Algunos elementos para interpretar la presencia de los varones en los procesos de salud reproductiva. Cad Saúde Pública 1998; 14(Supl. 1): 87-96.

9. Vilhena M. Sexualidade masculina do adolescente Perspectivas. Adolesc Saude 2013; 10(Supl. 3): 67-71.
10. Silva CB, Gama CS, Souza DT, Paula LP, Mucenic M, Foppa M. Iniciação sexual em estudantes secundaristas de Porto Alegre, RS, 1990. Rev AMRIGS 1993; 37(2): 88-92.

11. Carlini-Cotrim B, Gazal-Carvalho C, Gouveia N. Comportamento de saúde entre jovens estudantes das redes pública e privada da área metropolitana do Estado de São Paulo. Rev Saúde Pública 2000; 34(6): 636-45.

12. Nascimento LCS, Lopes CM. Atividade sexual e doenças sexualmente transmissíveis em escolares do $2^{\circ}$ grau de Rio Branco-Acre, Brasil. Rev Latino-am Enfermagem 2000; 8(1): 107-13.

13. Martins LBM, Costa-Paiva LHS, Osis MJD, Souza MH, Pinto-Neto AM, Tadini V. Fatores associados ao uso de preservativo masculino e ao conhecimento sobre DST/ AIDS em adolescentes de escolas públicas e privadas do Município de São Paulo, Brasil. Cad Saúde Pública 2006; 22(2): 315-23.

14. Brasil. Instituto Brasileiro de Geografia e Estatística. Pesquisa Nacional de Saúde do Escolar. Rio de Janeiro: IBGE; 2009.

15. Malta DC, Sardinha LMV, Brito I, Gomes MRO, Rabelo M, Morais Neto OL, Penna GO. Orientaçõesde saúde reprodutiva recebidas na escola - uma análise da Pesquisa Nacional de 
Saúde do Escolar nas capitais brasileiras e no Distrito Federal, 2009. Epidemiol Serv Saúde2011; 20(4): 481-90.

16. Oliveira-Campos M, Giatti L, Malta D, Barreto SM. Contextual factors associated with sexual behavior among Brazilian adolescents. Ann Epidemiol 2013; 23(10): 629-35.

17. Vieira AS, Guimarães EMB, Barbosa MA, Turchi MD, Alves MFC, Seixas MSC. Fatores associados ao uso do preservativo em adolescentes do gênero feminino no município de Goiânia. DST -J Bras Doenças Sex Transm 2004; 16(3): 77-83.

18. Marques ES, Mendes DA, Tornis NHM, Lopes CLR, Barbosa MA. O conhecimento dos escolares adolescentes sobre doenças sexualmente transmissíveis. Rev Eletron Enferm 2006; 8(1): 58-62.

19. Coelho RFS, Souto TG, Soares LR, Lacerda LCM, Matão MEL. Conhecimentos e crenças sobre doenças sexualmente transmissíveis e HIV / AIDS entre adolescentes e jovens de escolas públicas estaduais da região Oeste de Goiânia. Rev Patol Trop 2011; 40(1): 56-66.

20. Szwarcwald CL, Damacena GN. Amostras complexas em inquéritos populacionais: planejamento e implicações na análise estatística dos dados. Rev Bras Epidemiol 2008; 11(Suppl 1): 38-45.

21. Organização das Nações Unidas. Programme of Action of the United Nations International Conference on population \&Development. Cairo: ONU; 1994. Disponível em: http:// www.iisd.ca/Cairo/program/p01000.html (Acessado em 6 de dezembro de 2011).

22. Borges ALV, Latorre MRDO, Schor N. Fatores associados ao início da vida sexual de adolescentes matriculados em uma unidade de saúde da família da zona leste do Município de São Paulo, Brasil. Cad Saúde Pública 2007; 23(7): 1583-94.

23. Cruzeiro ALS, Souza LDM, Silva RA, Pinheiro RT, Rocha CLA, Horta BL. Comportamento sexual de risco: fatores associados ao número de parceiros sexuais e ao uso de preservativo em adolescentes. Ciênc Saúde Coletiva 2010; 15(Suppl. 1): 1149-58.

24. BrêtasJRS, Ohara CVS, Jardim DP, Aguiar Junior W, Oliveira JR. Aspectos da sexualidade na adolescência. Ciênc Saúde Coletiva 2011; 16(7): 3221-28.
25. Centers for Disease Control and Prevention. Trends in the Prevalence of Sexual Behaviors. National YRBS: 19912009. Atlanta: CDC; 2009. Disponível em: http:/ / www.cdc.gov/healthyyouth/yrbs/pdf/us_sexual_ trend_yrbs.pdf (Acessado em 1 de fevereiro de 2012).

26. Ministério da Saúde. Decreto no 6286, de 5 de dezembro de 2007. Institui o Programa Saúde na Escola-PSE. Brasília: Ministério da Saúde; 2007.

27. Brasil. Ministério da Saúde. Coordenação Nacional DST/AIDS. Centro Brasileiro de Análise e Planejamento (CEBRAP). Pesquisa sobre comportamento sexual da população brasileira e percepções sobre HIV/AIDS. Brasília: Ministério da Saúde; 2000.

28, Borges ALV, Schor N. Início da vida sexual na adolescência e relações de gênero: um estudo transversal em São Paulo, Brasil, 2002. Cad Saúde Pública 2005; 21(2): 499-507.

29. Upchurch DM, Levy-Storms L, Sucoff CA, Aneshensel CS. Gender and ethnics differences in the timing of first sexual intercourse. Fam Plann Perspect 1998; 30(3): 121-7.

30. Brasil. Ministério da Saúde. Secretaria de Vigilância em Saúde. Departamento de DST, Aids e Hepatites virais. Pesquisa de Conhecimentos, Atitudes e Práticas da População Brasileira de 15 a 64 anos de idade. Brasília: Ministério da Saúde; 2011.

31. Moura LR, Lamounier JR, Guimarães PR, Duarte JM, Beling MTC, Pinto JA, et al. A lacuna entre o conhecimento sobre HIV/AIDS e o comportamento sexual: uma investigação com adolescentes de Vespasiano, Minas Gerais, Brasil. Cad Saúde Pública 2013; 29(5): 1008-18.

32. Brasil. Instituto Brasileiro de Geografia e Estatística. Pesquisa Nacional por Amostra de Domicílios 2009. Rio de Janeiro: IBGE; 2009.

33. Togni AC, Carvalho MJS. A escola noturna de ensino médio no Brasil. Rev Iberoamericana de Educación 2007; 44: 61-76.

Received on: 01/18/2014

Final version presented on: 03/20/2014

Accepted on: 03/24/2014 